\title{
THE ABILITY OF FAST-GROWING TRANSGENIC AFRICAN CATFISH (Clarias gariepinus) ON PREDATOR AVOIDANCE
}

\author{
Huria Marnis\# ${ }^{\#}$ Bambang Iswanto, Imron, Selny Febrida, and Raden Roro Sri Pudji Sinarni Dewi \\ Research Institute for Fish Breeding
}

\begin{abstract}
Research Institute for Fish Breeding has produced transgenic African catfish (Clarias gariepinus) containing stripped catfish growth hormone gene (PcCBA-PhGH) with growth $19.86 \%$ faster than that of non-transgenic fish. This fish has high potential to be released and utilized for fish farming sector to increase national production. However, there is not yet information about environmental risk of this fish. One of the major fitness traits determining potential environmental risk is predator avoidance. This study aimed to determine the predator avoidance ability of transgenic African catfish in an experimental laboratory condition. In this study, thirty five individuals each of transgenic and non-transgenic with body weight of about $0.1 \pm 0.019$ $g$ were communally stocked in $60 \mathrm{~cm} \times 40 \mathrm{~cm} \times 40 \mathrm{~cm}$ aquarium with limited feeding frequency (ad libitum twice a day). One day after the fish were stocked, the predators were added to each aquarium. The nontransgenic and transgenic with body weight of $1.0 \pm 0.024 \mathrm{~g}$ were stocked as predators as many as five individual in each aquarium. After approximately two weeks of predation, all remaining fish were collected for transgenic verification by PCR method. Genomic DNA was isolated from fin tissue of individually survivors. The results of this study showed that the transgenic fish had worse predator avoidance and lower cannibal than non-transgenic $(P<0.05)$. There was no significant difference in growth performance between transgenic and non-transgenic African catfish $(P>0.05)$ in limited food. The transgenic fish may have lower fitness than non-transgenic.
\end{abstract}

KEYWORDS: predator avoidance; transgenic; environmental risk; Clarias gariepinus

\section{INTRODUCTION}

African catfish (Clarias gariepinus) is one commodity which aquaculture development is favored by the Ministry of Marine Affairs and Fisheries. African catfish has long been grown in Indonesia. However, the genetic quality of African catfish in Indonesia has decreased in growth rate, so that the necessary requires genetic improvement. Genetic improvement in the establishment of a rapid growth strain of African catfish might be achieved through transgenesis. The phenotype of African catfish transgenic have not been shaped by many generation of selection. A single generation, the characteristics of the organism have been modified with no opportunity for selection and adaptation to their environment. Growth rate is one character that has been manipulated in transgenic fish. The fast-growing transgenic African catfish was produced using the method of sperms electroporation

\footnotetext{
\# Correspondence: Research Institute for Fish Breeding

Jl. Raya 2 Pantura Sukamandi, Subang 41263, West Java, Indonesia. Phone: + (0260) 520500

E-mail: marnis.huria@gmail.com
}

as a carrier PcCBA-PhGH plasmid in 2011 (Dewi, 2010). In the last study, the $F_{2}$ populations of transgenic African catfish produced 2-fold fast growing performance than non-transgenic (Marnis et al., 2015).

However, the fish from genetically modified is still controversial. Although many researches have done on transgenic fish such as growth performance of transgenic fish (Morales et al., 2001; Nam et al., 2001; Lu et al., 2002). Appetites, feeding motivation, nutritional set points, and feed conversion ratio of transgenic fish (Cook et al., 2000; Sundström et al., 2004; Raven et al., 2006; Oakes et al., 2007) development and earlier maturation age of transgenic fish (Devlin et al., 2004; Sundström et al., 2003), production of elevated $\mathrm{GH}$ of transgenic fish (Devlin et al., 2000; Kang \& Devlin, 2004), transgene expression throughout the body (Mori \& Devlin, 1999), only a little information is available regarding the environmental risks posed.

One of the methods that could be used for environment safety testing was by examining the predator avoidance. There are two important factors in determining whether an animal should risk exposure 
to a predator, namely: parameters that affect mortality rates (i.e. the probability of being killed by a predator over a discrete period) and growth rates (e.g. the life history characteristics of the fish, particularly the future fitness benefits associated with food) (Abrahams \& Sutterline, 1999). This study aimed to determine the predator avoidance ability of transgenic African catfish in an experimental laboratory condition.

\section{MATERIAL AND METHOD}

\section{Animal and Sample Collection}

In this study, we used $F_{3}$ transgenic African catfish, carrying the pCcBA-PhGH construct (Dewi, 2010). All fish were derived from a single family of African catfish (Clarias gariepinus) and originated from the collection in Research Institute for Fish Breeding, Sukamandi, Indonesia.

\section{Predator Avoidance and Anti-Predator Responses of Transgenic African Catfish}

In this study, thirty five individuals each of transgenic and non-transgenic with body weight about $0.1 \pm 0.019 \mathrm{~g}$ were communally stocked in each 60 $\mathrm{cm} \times 40 \mathrm{~cm} \times 40 \mathrm{~cm}$ aquaria with limited feeding frequency (ad libitum twice a day). Normally, fish has feeding frequency ad libitum three to four times a day in regular culture. One day after the fish were stocked, the predators were added to the aquarium. The nontransgenic and transgenic African catfish with body weight about $1.0 \pm 0.024 \mathrm{~g}$ were stocked as predators (five individuals each aquarium). After approximately two weeks of predation, all remaining fish were collected for transgenic verification and measured average body weight. Transgenic fish was identified using PCR method with DNA template that has been extracted from fin tissue.

\section{DNA Extraction}

Genomic DNA of each sample was extracted using DNA extraction kit following the protocols recommended by manufacturer (Genejet Genomic DNA Purification, Thermo Scientific). Briefly, the protocol consists series of steps including Cell lysis, DNA precipitation, binding DNA to the column, washing, and elution. Cell lysis was performed by weighing of approximately $10 \mathrm{mg}$ of tissue sample and to check the success of genomic DNA extraction process, the sample was run on mini horizontal gel electrophoresis. The sample was loaded in to the $1.5 \%(\mathrm{w} / \mathrm{v})$ agarose gel, powered with 65 volt electricity and run for 50 minutes. The gel was then stained with gelRed (biotium) $1 \mu \mathrm{g} / \mathrm{ml}$ and viewed using gel documentation system ultraviolet transillumination.

\section{Polymerase Chain Reaction (PCR)}

Amplification of transgene was performed using thermal cycling system (mycycler, Biorad). PCR standard was performed in a final volume of $25 \mu \mathrm{L}$, using a commercial kit master mix fast start PCR master (Roche, Germany). The PCR was used to amplify a 1,300-bp fragment transgene with primers ACT 107F (5'- GTG TGT GAC GCT GGA CCA ACT - 3') and PhGH2-R (5'CGA TAA GCA CGC CGA TGC CCA TTT-3 ') (Hidayani, 2009; Dewi, 2010), for 35 cycles: denaturing at $94^{\circ} \mathrm{C}$ for 30 secs, annealing at $55^{\circ} \mathrm{C}$ for 30 seconds, and extension at $72^{\circ} \mathrm{C}$ for one min. The amplification using the specific primer of $B$-actin was performed as internal control of DNA loading. The $\beta$ actin primers: bact-F (5'-TAT GAA GGT TAT GCT CTG CCC-3') and bact-R (5'-CAT ACC CAG GAA AGA TGG CTG-3') were designed from a catfish $B$-actin sequence (Accession JF303887.1). The reaction was incubated at $94^{\circ} \mathrm{C}$ for 30 secs, annealing at $55^{\circ} \mathrm{C}$ for 30 secs, and extension at $72^{\circ} \mathrm{C}$ for one min for 30 cycle and the PCR products were then separated on $1.5 \%(\mathrm{w} / \mathrm{v})$ agarose gel stained with gelRed (biotium) $1 \mu \mathrm{g} / \mathrm{mL}$ and visualized by ultraviolet transillumination.

\section{Data Analysis}

Mortality differences and mean body weights of transgenic and control of African catfish were compared using Student's t test.

\section{RESULTS AND DISCUSSION}

The result showed that the transgene was detected in juvenile of transgenic African catfish with the expected size product was 1,300-bp. The transgene was not detected in non-transgenic African catfish (Figure 1).

The result of this study showed that transgenic had worse predator avoidance and lower cannibal than that of non-transgenic $(P<0.05)$ (Table 1). Similarly, the transgenic channel catfish (Ictalurus punctatus) containing growth hormone of salmon (RSVLTR-rtGH DNA complementary, RSVLTR-rtGH ${ }_{2}$, and RSVLTR-CSGH CDNA) also had worse predator avoidance (Micropterus salmoides and Lepomis cyanellus) than that of nontransgenic (Dunham et al., 1999). In addition, Sundström et al. (2004b) reported that transgenic Coho salmon (Oncorhynchus kisutch) had worse predator avoidance than that of non-transgenic. Later, Wei $\&$ Yan (2010) have demonstrated that the transgenic common carp had worse predator avoidance than that of non-transgenic.

Possibly, the swimming speed of transgenic African catfish was slower than that of non-transgenic, in order to be more vulnerable to be attacked by preda- 


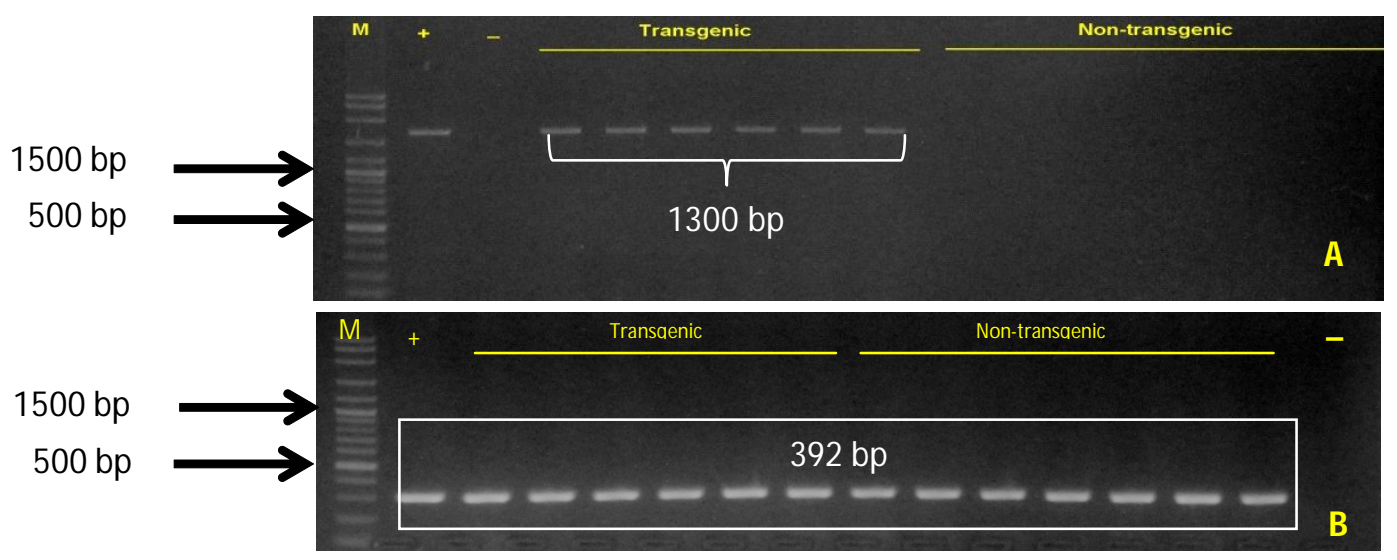

Figure 1. Detection of transgene (PhGH) and $\beta$-actin gene in African catfish (Clarias gariepinus) transgenic and non-transgenic juvenile using PCR method; A). detection transgene, $B)$. detection $\beta$-actin gene, (-) indicates a negative control, $(+)$ indicates a positive control. The expected size of PhGH gene the amplified fragment is $1,300 \mathrm{bp}$ and the expected size of $\beta$-actin the amplified fragment is $392 \mathrm{bp}$

tors. Several experiments reported that the swimming speed of transgenic fish containing the growth hormone were slower than that of nontransgenic (DeLiang et al., 2007; Lee et al., 2003; Farrell et al., 1997). The swimming speed of each type of fish determines its ability to survive in the environment (Swanson et al., 1998). Furthermore, predator avoidance of transgenic African catfish correlated with willingness to risk exposure to a predator. Abrahams $\&$ Sutterline (1999) reported that transgenic salmon had rate of feed consumption that were approximately five times than that of the control fish and rate of movement approximately double than that of controls. Transgenic salmon also spent significantly more time feeding in the presence of the predator, and consumed absolutely more food at that location. When there was a real risk of mortality, control fish almost completely avoided the dangerous location. Transgenic fish continued to feed at this location, but at a reduced level. These data demonstrate that the growth enhancement associated with the transgenic manipulation increases the level of risk these fish are willing to incur while for aging.

If transgenic African catfish was accidentally released into nature, they would most likely decrease in number because of their increased susceptibility to predators, and eventually the transgenic African catfish would be eliminated. Alternatively, if the transgenic African catfish was not totally eliminated, the population fitness could be lowered because of the increased vulnerability to predation. Dunham et al. (1999) reported that the selection theory would predict transgenic fish elimination, especially because the fitness trait is predation avoidance and predation pressure is severe in the natural environment for transgenic fish. These research findings indicate that transgenic African catfish may have lower fitness than that of non-transgenic.

There was no significant difference in growth performance between transgenic and non-transgenic African catfish $(P>0.05)$ (Table 1$)$. These results suggest that transgenic African catfish would not exhibit their fast growth in limited food. Possibly, transgenic African catfish did not express their growth potential where food was limited. Dunham et al. (1999) reported that limited food did not allow the transgenic channel catfish (Ictalurus punctatus) to express their growth. Likewise, the growth performance of triploid oysters would not increase where food was limited (Dunham, 1996). In Addition, Gregory \& Wood (1999) reported that negative growth effects were more severe in the fish with food limitation.

\section{CONCLUSION}

The result of this study showed that transgenic African catfish had worse predator avoidance and lower cannibal than non-transgenic significanly. There was no significant difference in growth performance between transgenic and non-transgenic African catfish where treated with limited feeding frequency. These research findings indicate that the ecological risk of transgenic African catfish would be low or non-existent. Moreover, the transgenic fish may have lower fitness than non-transgenic. 
Table 1. The survival rate of transgenic African catfish and average body weight in predator avoidance test

\begin{tabular}{|c|c|c|c|c|c|c|}
\hline \multirow{3}{*}{ Predator } & \multicolumn{4}{|c|}{ Survival rate } & \multicolumn{2}{|c|}{ Body weight (g) } \\
\hline & \multicolumn{2}{|c|}{ Transgenic } & \multicolumn{2}{|c|}{ Non-transgenic } & \multirow{2}{*}{ Transgenic } & \multirow{2}{*}{ Non-transgenic } \\
\hline & $\mathbf{N}$ & $\%$ & $\mathbf{N}$ & $\%$ & & \\
\hline \multirow{3}{*}{ Non-transgenic } & 5 & $7,14^{\mathrm{a}}$ & 15 & $21,43^{b}$ & $0.08 \pm 0.03^{\mathrm{ns}}$ & $0.09 \pm 0.04^{\mathrm{ns}}$ \\
\hline & 3 & $4,29^{a}$ & 27 & $38,57^{b}$ & $0.07 \pm 0.03^{\mathrm{ns}}$ & $0.07 \pm 0.05^{\mathrm{ns}}$ \\
\hline & 2 & $2,86^{\mathrm{a}}$ & 24 & $34,27^{b}$ & $0.06 \pm 0.02^{\mathrm{ns}}$ & $0.05 \pm 0.02^{\mathrm{ns}}$ \\
\hline \multirow{3}{*}{ Transgenic } & 30 & $42,86^{\text {ns }}$ & 32 & $45,71^{\text {ns }}$ & $0.06 \pm 0.02^{\mathrm{ns}}$ & $0.05 \pm 0.02^{\mathrm{ns}}$ \\
\hline & 33 & $47,14^{\text {ns }}$ & 33 & $47,14^{\text {ns }}$ & $0.08 \pm 0.04^{\mathrm{ns}}$ & $0.09 \pm 0.04^{\mathrm{ns}}$ \\
\hline & 28 & $40,00^{\text {ns }}$ & 27 & $38,57^{\mathrm{ns}}$ & $0.09 \pm 0.04^{\mathrm{ns}}$ & $0.08 \pm 0.04^{\mathrm{ns}}$ \\
\hline \multirow{3}{*}{ None } & 35 & $50,00^{\text {ns }}$ & 34 & $48,57^{\mathrm{ns}}$ & $0.09 \pm 0.04^{\mathrm{ns}}$ & $0.10 \pm 0.04^{\mathrm{ns}}$ \\
\hline & 33 & $47,14^{\text {ns }}$ & 34 & $48,57^{\text {ns }}$ & $0.09 \pm 0.04^{\mathrm{ns}}$ & $0.08 \pm 0.04^{\mathrm{ns}}$ \\
\hline & 32 & $45,71^{\text {ns }}$ & 33 & $47,14^{\text {ns }}$ & $0.07 \pm 0.03^{\mathrm{ns}}$ & $0.07 \pm 0.04^{\mathrm{ns}}$ \\
\hline
\end{tabular}

Remark: ns = non significance

\section{ACKNOWLEDGEMENT}

The authors appreciate the funding support from APBN with DIPA No. 32.11.2.660052/2015 in Research Institute for Fish Breeding, Sukamandi. We thank to Mr. Puji Sumargono, Mr. Ilma Lizandri, Mr. Didi, Miss Maya Febriana Pangestika, and Miss Putri Widyastuti for the support of this research.

\section{REFERENCES}

Abrahams, M.V., \& Sutterlin, A. (1999). The foraging and anti-predator behaviour of growth enhanced transgenic Atlantic salmon. J. Anim. Behav., 58, 933-942.

Cook, J.T., McNiven, M.A., Richardson, G.F., \& Sutterlin, A.M. (2000). Growth rate, body composition and feed digestibility/conversion of growth-enhanced transgenic Atlantic salmon (Salmo salar). Aquaculture, 188, 15-32.

Deliang, L., CuiZhang, F., Wei, H., Shan, Z., YaPing, W., \& ZouYan, Z. (2007). Rapid growth cost in "All-fish" growth hormone gene transgenic carp: reduced critical swimming speed. Chinese Science Bulletin, 52(11), 1501-1506.

Devlin, R.H., Biagi, C.A., \& Yesaki, T.Y. (2004). Growth, viability and genetic characteristics of $G H$ transgenic Coho salmon strains. Aquaculture, 236, 607-632.

Devlin, R.H., Swanson, P., Clarke, W.C., Plisetskaya, E., Dickhoff, W., Moriyama, S., Yesaki, T.Y., \& Hew, C.L. (2000). Seawater adaptability and hormone levels in growth-enhanced transgenic Coho salmon (Oncorhynchus kisutch). Aquaculture, 191, 367-385.
Dewi, R.R.S.P.S. (2010). Studies over-expression of the growth hormone gene by electrophoresis sperm to create transgenic Stripped catfish grow faster. Dissertation, $75 \mathrm{pp}$.

Dunham, R.A. (1996). Contribution of genetically improved aquatic organisms to global food security. Presented at the International Conference on Sustainable Contribution of Fisheries to Food Security, sponsored by the Government of Japan and FAO, FAO, Rome, Italy.

Dunham, R.A., Chitmanat, C., Nichols, A., Argue, B., Powers, D.A., \& Chen, T.T. (1999). Predator avoidance of transgenic channel catfish containing salmonid growth hormone genes. Marine Biotechnology, 1, 545-551.

Farrell, A.P., Bennett, W., \& Devlin, R.H. (1997). Growth-enhanced transgenic salmon can be inferior swimmers. Canadian Journal Zoolgy, 75, 335337.

Gregory, T.R., \& Wood, C.H. (1999). The effects of chronic plasma cortisol elevation on the feeding behavior, growth, competitive, ability, and swimming performance of juvenile rainbow trout. Physiological and biochemical zoology: Ecological and evolutionary approaches, 72(3), 286-295.

Hidayani, A.A. (2009). Isolation and effectivity in driving target gene expression on common carp (Cyprinus carpio). Thesis. $35 \mathrm{pp}$.

Kang, D.Y., \& Devlin, R.H. (2004). Effects of 3,5,3 0 triiodo-L-thyronine (T) and 6-npropyl-2-thiouracil (PTU) on growth of GH-transgenic Coho salmon (Oncorhynchus kisutch). Fish Physiol. Biochem., 29, 77-85. 
Lee, C.G., Devlin, R.H., \& Farrell, A.P. (2003). Swimming performance, oxygen consumption and excess post-exercise oxygen consumption in adult transgenic and ocean-ranched coho salmon. Journal of Fish Biology, 62, 753-766.

Lu, J.-K., Fu, B.-H., Wu, J.-L., \& Chen, T.T. (2002). Production of transgenic silver sea bream (Sparus sarba) by different gene transfer methods. Mar. Biotechnol., 4, 328-337.

Marnis, H., Iswanto, B., Suprapto, R., Imron, \& Dewi, R.R.S.S. (2015). Performance and zigosity of F2 transgenic African catfish (Clarias gariepinus) containing growth hormone gene of stripped catfish (Pangasianodon hypophtalmus). Aquaculture Research Journal, 10(2), 161-168.

Morales, R., Herrera, M.T., Arenal, A., Cruz, A., Hernandez, O., Pimentel, R., Guillen, I., Martinez, R., \& Estrada, M. (2001). Tilapia chromosomal growth hormone gene expression accelerates growth in transgenic zebraûsh (Danio rerio). EJB Electron. J. Biotechnol, 4, 1-7.

Mori, T., \& Devlin, R.H. (1999). Transgene and host growth hormone gene expression in pituitary and nonpituitary tissues of normal and growth hormone transgenic salmon. Mol. Cell. Endocrinol., 149, 129-139.

Nam, Y.K., Noh, J.K., Cho, Y.S., Cho, H.J., Cho, K.-N., Kim, C.G., \& Kim, D.S. (2001). Dramatically accelerated growth and extraordinary gigantism mud loach (M isgurnus mizolepis). Transgenic Res., 10, 353362.

Oakes, J.D., Higgs, D.A., Eales, J.G., \& Devlin, R.H. (2007). Inûuence of ration level on the growth performance and body composition of non- transgenic and growth hormone-transgenic Coho salmon (Oncorhynchus kisutch). Aquaculture, 265, 309-324.

Raven, P.A., Devlin, R.H., \& Higgs, D.A. (2006). Inûuence of dietary digestible energy content on growth, protein and energy utilization and body composition of growth hormone transgenic and non-transgenic Coho salmon (Oncorhynchus kisutch). Aquaculture, 254, 730-747.

Sundström, L.F., Devlin, R.H., Johnsson, J.I. \& Biagi, C.A. (2003). Vertical position reûects increased feeding motivation in growth hormone transgenic Coho salmon (Oncorhynchus kisutch). Ethology, 109, 701-712.

Sundström, L.F., Lõhmus, M., Devlin, R.H., Johnsson, J.I., Biagi, C.A., \& Bohlin, T. (2004). Feeding on proûtable and unproûtable prey: comparing behaviour of growth enhanced transgenic and normal Coho salmon (Oncorhynchus kisutch). Ethology, 110, 381-396.

Sundström, L.I., Lohmus, M., Johnsson, J.I., \& Devlin, R.H. (2004b). Growth Hormone transgenic salmon pay for growth potential with increased predation mortality. Proc. R. Soc. Lond., 271, S350-S352.

Swanson, C., Young, P.S., \& Cech, J.J. (1998). Swimming performance of delta smelt: maximum performance, and behavioral and kinematic limitations on swimming at submaxial velocities. Journal of Experimental Biology, 201, 333-345.

Wei, H., \& Yan, Z.Z. (2010). Integration mechanisms of transgenes and population fitness of $\mathrm{Gh}$ transgenic fish. Science China Life Sciences, 53(4), 401-408. 